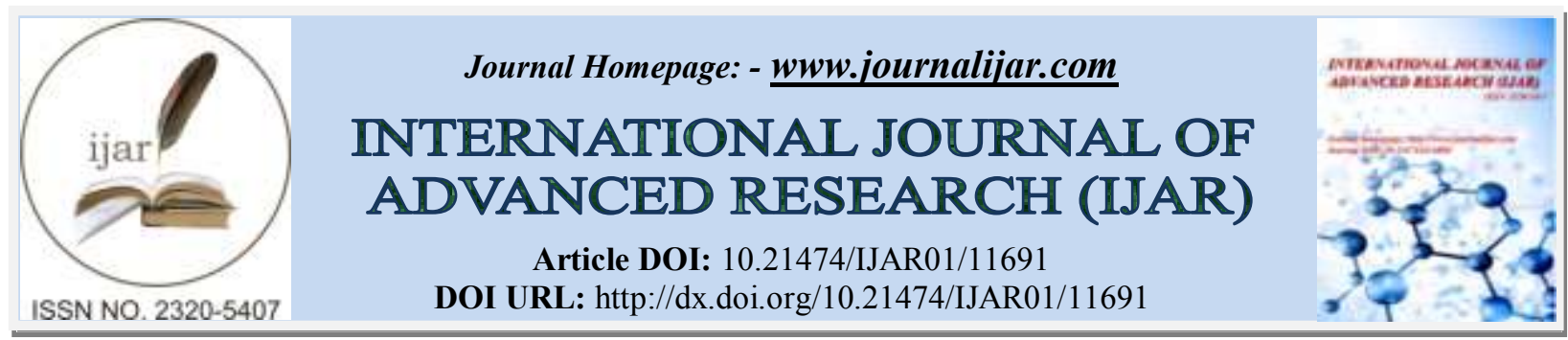

RESEARCH ARTICLE

\title{
THE UNDERSTANDING OF PARENTS ON THE ROLE OF TEACHER AND THEIR VIEWS ON THE GROWING ROMANTIC RELATIONSHIP BETWEEN STUDENT AND TEACHER
}

\author{
Jacinto Y. Bustamante
}

Nueva Ecija University of Science and Technology, Cabanatuan City, Nueva Ecija, Philippines.

\section{Manuscript Info}

(...........................

Manuscript History

Received: 10 July 2020

Final Accepted: 14 August 2020

Published: September 2020

Key words:-

In Loco Parentis, Role Of Teacher,

Romantic Relationship, Student-Teacher

Relationship

\begin{abstract}
This study has been undertaken to determine the level of understanding of 134 parents of higher education students on the role of teacher and their views about the growing existence of student-teacher romantic relationship. The study examined the level of understanding of parents to the role of the teacher in the students and their view to the romantic relationship of student and teacher. The study utilized a descriptive research design. The researcher used a convenient sampling procedure in gathering data. The researcher used likert scale to measure the parents' agreement with the questions. The findings revealed that parents understood the role of the teacher in the student. The study also revealed that it is normal nowadays the romantic relationship between teacher and student from the point of view of the parents. However, the study found that there is a role that teachers should observed which is not clear to the respondents and there are some questions regarding romantic relationship of student and teacher that parents cannot decide whether they agree or disagree. The result of the study favored social acceptance to that kind of student-teacher relationship where that kind of acceptance may be a threat on the principle of in loco parentis role which is observed in educational institutions.
\end{abstract}

Copy Right, IJAR, 2020,. All rights reserved.

\section{Introduction:-}

From the beginning the reason for the increase of people is due to parents. It is the parents who brought the child in this world and they were the ones who contributed a lot in the development of society (Ceka, A. \& Murati, R, 2016). Parents have always been actively involved in enhancing their children's development and educational progress (Desforges, C. with Abouchaar, A. 2003). The future of the child is not depends solely on education in school but also on how the parents raised their children at home. The parents and educational institutions have a great role in developing children and should give all the best they can just to ensure their well being.

A teacher is a person who is respected in society and community. As such they are expected to have high standards of morality. They must be the role model of their students and their community. As a person in authority in educational institution, a teacher plays major roles in developing students. They are expected to share wisdom and expertise to students and ensure that students are learning in a safe and productive environment (Betterteam, 2020) While students are under teacher's custody the latter has the obligation to exercise due diligence to ensure that students are far from all kinds of unexpected misfortunes. 
On the other hand, students as learners play a crucial role in education. They must study hard to get high grades. They must be active in acquiring knowledge for they are believed to be the future of the nation. As someone who is under the authority of school and teachers, students have the obligation to respect the rules of the school and give high regards to teachers especially when the students are actually dealing with their teachers. Students must imprint in their mind that teachers are the substitute of the parents once the student is sent to school and as such teachers are treated by law as substitute parent of the student.

However, despite that parents, teachers, and students have the roles to be played in the society there is an unexpected happening and that is the closer relations between student and teacher. In the Philippines, upon the implementation of K-12, the gap between the age of students and teachers is no longer visible. The students became almost the same age as the teacher. This paved the way for students and their teachers to get closer and be friends. Since the teacher and students are just about the same age it is very possible that their interest, habits, aspirations, and goals are almost the same which makes them even closer.

In the Philippines there are some cases where the closeness of student and teacher leads to romantic relationship. In the case of Evelyn Chua-Qua vs Jacoba Clave and Tay Tung High School Inc. the teacher and student got in love with each other. Eventually they got married with an age gap of 14 years (G.R. No. 49549, August 30, 1990 as cited by Lopez, A. III, 2015). The teacher was dismissed from work on the ground of immorality but the Supreme Court of the Philippines ruled on the contrary and states that if the two eventually fell in love, despite the disparity in their ages and academic levels, this only lends substance to the truism that heart has reasons of its own which reason does not know (Estrada, J N M, 2018). But, definitely, yielding to this gentle and universal emotion is not to be so casually equated with immorality (Projectjurisprudence.com, 2018).

From the cited case above it is very evident that for many decades the teacher gets involve with sweet relations to student. More and more teachers are getting married with their students or former students nowadays and as a result it seems that student-teacher romantic relationships are accepted by parents and community. Through this study the researcher will be able to determine the view of the parents on the romantic relationship of the student and the teacher. Specifically, it aimed to determine level of understanding of the parents to the role of the teacher in the student, their views in student-teacher romantic relationship, and its implication on the principle of in loco parentis role.

\section{Methodology:-}

This study is a descriptive research design. A descriptive research design aims to accurately and systematically describe a population, situation or phenomenon (Mc Combes, S, 2020). The respondents of the study were 134 parents of higher education students residing in Cabanatuan City, Nueva Ecija, Philippines. The researcher utilized a convenient sampling procedure, meaning, those who are readily available during the time this study was conducted. The researcher utilized a self-devised questionnaire. There were 150 questionnaires and $89.34 \%$ of questionnaires were retrieved. The questionnaire was composed of two parts. Part I is composed of the role of a teacher and Part II is the view of the parents in romantic relationship between student and teacher. The data gathered were statistically performed using frequency count, percentage, and weighted mean. Each response to every item was evaluated according to the following scale: 1.00 to 1.79 Strongly Disagree; 1.80 to 2.59 Disagree; 2.60 to 3.39 Can't Say whether Agree or Disagree; 3.40 to 4.19 Agree; 4.20 to 5.00 Strongly Agree.

\section{Results and Discussion:-}

\section{Role of Teacher in the Student}

Table 1 presents the level of understanding of the respondents to the role of the teacher to students.

The table revealed that the respondents were strongly agree $(\mathrm{Wm}=4.43)$ that the role of the teachers is to teach students knowledge, lecture, and provide hands on learning activities. They hold with strong affirmation $(\mathrm{Wm}=4.35)$ that a teacher acts as a substitute of parents when the student is under the teacher's supervision and custody.

The respondents agree $(\mathrm{Wm}=4.07)$ that teachers inspire students to have a positive social behavior and affirm $(\mathrm{Wm}=4.04)$ that teachers cultivate students' interest in education and development. They also affirm that one of the roles of teachers is to serve as role model in school and community(Wm=3.99). The parent-respondents agree $(\mathrm{Wm}=3.99)$ that teachers ensure that all students are learning in a safe and productive environment. 
Table 1:- Parents' Level of Understanding on the Role of A Teacher.

\begin{tabular}{|l|l|l|}
\hline Item & Weighted Mean & Verbal Interpretation \\
\hline $\begin{array}{l}\text { 1. Teach students knowledge, lecture, and provide } \\
\text { hands on learning activities }\end{array}$ & 4.43 & Strongly Agree \\
\hline 2. Inspire students to have a positive social behavior & 4.07 & Agree \\
\hline 3. A role model in school and community & 3.99 & Agree \\
\hline $\begin{array}{l}\text { 4. Encourage students to strive to be the best they } \\
\text { can }\end{array}$ & 3.88 & Agree \\
\hline $\begin{array}{l}\text { 5. Cultivate students interest in education and } \\
\text { development }\end{array}$ & 4.04 & Agree \\
\hline $\begin{array}{l}\text { 6. Ensure all students are learning in a safe and } \\
\text { productive environment }\end{array}$ & 3.99 & Agree \\
\hline $\begin{array}{l}\text { 7. Act as a substitute of parents when the student is } \\
\text { under the teacher's supervision and custody }\end{array}$ & 4.35 & Strongly Agree \\
\hline $\begin{array}{l}\text { 8. Exercise due diligence in taking care of students } \\
\text { 9. Demonstrates proper behavior and protects the } \\
\text { students against sexual, emotional, physical and } \\
\text { other forms of abuse and violence }\end{array}$ & 3.42 & Disagree \\
\hline $\begin{array}{l}\text { 10. Cooperates in shaping the student to love the } \\
\text { country and fellow citizens }\end{array}$ & 3.47 & Agree \\
\hline Overall Weighted Mean & $\mathbf{3 . 8 8}$ & Agree \\
\hline \begin{tabular}{l} 
Asigether Agree or \\
\hline
\end{tabular}
\end{tabular}

Aside from the above roles of the teacher which the respondents affirmed, they also agree that it is the role of the teachers to encourage students to strive to the best they can $(\mathrm{Wm}=3.88)$ and conform to the question that teachers cooperate in shaping the student to love the country and fellow citizens $(\mathrm{Wm}=3.47)$. From the view point of the respondents based on the data gathered, they agree that teacher should demonstrates proper behavior and protects the students against sexual, emotional, physical and other forms of abuse and violence $(\mathrm{Wm}=3.42)$.

However, despite the fact that the respondents are aware on most of the roles of the teacher, based on the result of the study, the respondents cannot say whether they agree or disagree $(\mathrm{Wm}=3.19)$ as to the required diligence that a teacher should exercise in taking care of students.

As to the questions given to respondents, they obtained an overall weighted mean of 3.88 which means they agree to the questions given.

\section{Perception of the respondents on romantic relationship between student and teacher.}

Table 2 presents the perception of the parents on the romantic relationship between student and teacher.

As shown in table 2, the respondents agree $(\mathrm{Wm}=4.03)$ that it is normal for the teacher and student to fell in love with each other in today's time and they think that the future of the student will be better if his/her teacher is his/her relationship $(\mathrm{Wm}=3.53$ /Agree $)$. According to the result of the study the respondents agree $(\mathrm{Wm}=3.98)$ that parent should not be angry if his/her son/daughter has romantic relationship with his/her teacher and should respect the love between his/her son/daughter and the teacher $(\mathrm{Wm}=3.83)$ of the latter.

The data provides that the perception of the respondents to the romantic relationship between the student and teacher should no longer be considered prohibited( $\mathrm{Wm}=3.71$ /Agree) but they cannot say whether they agree or disagree $(\mathrm{Wm}=3.31)$ to the question that the love between a teacher and a student cannot be considered a teacher's abuse of his/her student because it is a mutual feeling between them. It only revealed that the students-teacher romantic relationship is going to be accepted in the society since it is gradually tolerated. However, since the respondents are undecided whether that kind of relationship is an abuse to students, it can be implied that such is a bar to the growing existence of student-teacher relationship and the teacher can be accused of abusing the student since the latter is vulnerable.

With respect to the question that there should be no barrier when it comes to love regardless of status in life, the respondents are neutral to that matter and the question has obtained 3.36 weighted mean with verbal interpretation of 
cannot say whether agree or disagree. The same stand appears to the answer of the respondents to the question that everyone should respect the romantic relationship of the student and teacher because it is a private affair. That question has obtained 3.24 weighted mean or they can't say whether they agree or disagree. These findings showed that even if the love between two persons having intimate feelings with each other should be respected for it is a private affair, it is not absolute for there are some instances that could prevent that love especially when such relationship will fall within the definitions of immorality.

As to the question that romantic relationship between student and teacher should be recognized in society, the respondents agree $(\mathrm{Wm}=3.71)$. However, they cannot say whether they agree or disagree $(\mathrm{Wm}=3.36)$ that it is time to acknowledge the romantic relationship between teacher and student. These findings revealed that even the respondents are ready for the social acceptance of student and teacher romantic relationship they think that this is not the proper time to acknowledge such situations.

Table 2:- Perception of the Respondents on Romantic Relationship between Student and Teacher.

\begin{tabular}{|c|c|c|}
\hline $\begin{array}{l}\text { Perception of the Parents on Romantic } \\
\text { Relationship of Student and Teacher }\end{array}$ & Weighted Mean & Verbal Interpretation \\
\hline $\begin{array}{l}\text { 1. It is normal for the teacher and student to fell } \\
\text { in love with each other in today's time }\end{array}$ & 4.03 & Agree \\
\hline $\begin{array}{l}\text { 2. Romantic relationship between student and } \\
\text { teacher should be recognized in society }\end{array}$ & 3.71 & Agree \\
\hline $\begin{array}{l}\text { 3. Everyone should respect the romantic } \\
\text { relationship of the student and teacher because it } \\
\text { is a private affair }\end{array}$ & 3.24 & $\begin{array}{l}\text { Can't Say whether Agree or } \\
\text { Disagree }\end{array}$ \\
\hline $\begin{array}{l}\text { 4. There should be no barrier when it comes to } \\
\text { love regardless of status in life }\end{array}$ & 3.36 & $\begin{array}{l}\text { Can't Say whether Agree or } \\
\text { Disagree }\end{array}$ \\
\hline $\begin{array}{l}\text { 5. The parent should not be angry if his/her } \\
\text { son/daughter has romantic relationship with } \\
\text { his/her teacher }\end{array}$ & 3.98 & Agree \\
\hline $\begin{array}{l}\text { 6. the love between a teacher and a student } \\
\text { cannot be considered a teacher's abuse of his } \\
\text { student because it is a mutual feeling between } \\
\text { them }\end{array}$ & 3.31 & $\begin{array}{l}\text { Can't Say whether Agree or } \\
\text { Disagree }\end{array}$ \\
\hline $\begin{array}{l}\text { 7. Parent should respect the love between his/her } \\
\text { son/daughter and teacher }\end{array}$ & 3.83 & Agree \\
\hline $\begin{array}{l}\text { 8. The romantic relationship between the student } \\
\text { and teacher should no longer be considered } \\
\text { prohibited }\end{array}$ & 3.71 & Agree \\
\hline $\begin{array}{l}\text { 9. The future of the student will be better if } \\
\text { his/her teacher is his/her relationship }\end{array}$ & 3.53 & Agree \\
\hline $\begin{array}{l}\text { 10. It is time to acknowledge the romantic } \\
\text { relationship between teacher and student in } \\
\text { society. }\end{array}$ & 3.36 & $\begin{array}{l}\text { Can't Say whether Agree or } \\
\text { Disagree }\end{array}$ \\
\hline Overall Weighted Mean & 3.60 & Agree \\
\hline
\end{tabular}

The respondents obtained an overall weighted mean of 3.60 to all the questions given to them regarding perception to the romantic relationship of student and teacher with verbal interpretation agree.

The Implication of Romantic Relationship between Student and Teacher on the Principle of In Loco Parentis Role of Teacher

A romantic student-teacher relationship is a prohibited act in the Philippines. As teachers, they stand in loco parentis and it is unthinkable for a teacher, who is recognized by law as substitute of parent, to have a romantic affair with student(Estrada, J N M. 2018). Today, the generation cuts the gap between student and teacher since most of them are almost of the same age and belong to the same generation. Despite the fact that the result of the study favors the recognition of romantic relationship between student and teacher in society and should not be prohibited for the respondents think that it is normal nowadays for the teacher and student to fall in love with each other and even if 
the respondents think that the future of the student will become better if his/her relationship is his/her teacher, such facts could not deny the reality that teachers are the substitute of parents (Herrington, S, 2017). As a substitute parent it is hard to imagine for teachers to have a romantic affair with students. If the Philippines, for instance, will allow the romantic student-teacher relationship, the principle of in loco parentis role of teachers will become meaningless. The students will be prone to abuses for they are vulnerable and easy to persuade and the parental authority of teachers over their students will become ineffective. The in loco parentis role is designed for the protection of the students for their best interest and should not be destroyed by acceptance of the people to the student-teacher romantic affair. Hence, the romantic relationship between student and teacher is a threat to the principle of in loco parentis role.

\section{Conclusion and Recommendations:-}

On the respondents view on the role of a teacher, most of respondents understood and are aware to the role of the teacher with high level of conformity. However, it is very alarming based on the result of the study that respondents do not know what kind of diligence a teacher should exercise in taking care of students. As a parent who will pass the responsibility to a teacher, parent should know that the diligence required is diligence of a good father of the family when the student is under supervision and custody of a teacher or school. On the issue of the growing existence of romantic relationship between student and teacher, the study shows that such seems to be accepted by the respondents for they believe that it is normal that student-teacher fell in love to each other and they are in the position that parents should respect the relationship of the student and teacher and they should not be angry once it happens. They also think that the student's future would be better when the teacher is the latter's relationship. Maybe this mind setting took place because many men in the country were unstable in life. Despite that the perception of the parents is going to the acceptance of student-teacher romantic affair, they still don't know if this is the time to acknowledge the same in the society and they are uncertain if such act is an act of taking advantage to students or not. Based on the foregoing, the researcher recommends that: Another research should be conducted in other places with the same topic as to this one to further determine the pulse of the people regarding romantic relationship between student and teacher. More respondents should be used as participants. The school should not tolerate the growing existence of student-teacher romantic relationship since it is against public policy in the country. The students and teachers should know their limitations in dealing with each other. The parents should be well informed that teachers are their substitute while the students are under the custody and supervision of the school. And Finally, the teachers should act as substitute of parents and not as lovers of students.

\section{References:-}

1. Betterteam, (2020). Job Description. www.betterteam.com/teacher-job-description

2. Ceka, A. \& Murati, R. (2016). The Role of Parents in the Education of Children, Journal of Education and

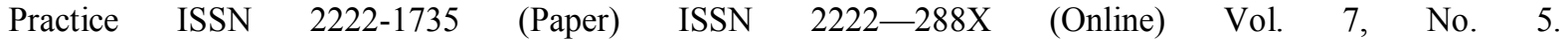
https://files.eric.ed.gov/fulltext/EJ1092391.pdf

3. Desforges, C. with Abouchaar, A. (2003). The Impact of Parental Involvement, Parental Support and Family Education on Pupil Achievement and Adjustment: A Literature Review, ISBN 1841859990 , June 2003. https://www.nationalnumeracy.org.uk/sites/default/files/the impact of parental involvement.pdf

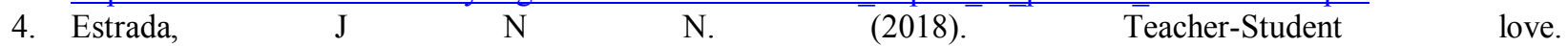
affairhttps://www.manilatimes.net/2018/02/14/opinion/analysis/teacher-student-love-affair/380023/

5. Evelyn Chua-Qua vs Jacoba Clave and Tay Tung High School Inc. (G.R. No. 49549, August 30, 1990)

6. Herrington, S. (2017). Is it OK for Student-Teacher Relationship to Turn Romantic? YJ Investigates. https:/www.yogajournal.com/lifestyle/yj-investigates-romantic-student-teacher-relationship

7. Lopez III, A. (2015). The heart has reasons of its own which reason does not know. https://attyangelo.com/2015/02/19/the-heart-has-reasons-of-its-own-which-reason-does-not-know/

8. Mc Combes, S. (2020). Descriptive Research. www.scribbr.com/methodology/descriptive-research/

9. Project Jurisprudence, (2018). SC: 30YO TEACHER, 16YO STUDENT ROMANCE NOT ILLEGAL. https://www.projectjurisprudence.com/2018/05/sc-30yo-teacher-16yo-student-romance-not-illegal.html. 